\title{
PENGUKURAN KADAR SISA CHLOR SEBELUM DAN SESUDAH PEMAKAIAN AIR KOLAM RENANG DI WATER PARK SURYA YUDHA KABUPATEN BANJARNEGARA TAHUN 2015
}

\author{
Kencana Handayani ${ }^{1)}$, Sugeng Abdullah ${ }^{2)}$ \\ Jurusan Kesehatan Lingkungan, Politeknik Kesehatan Kemenkes Semarang, \\ Jl.Raya Baturaden KM 12 Purwokerto, Indonesia
}

\begin{abstract}
Abstrak
Penyehatan kolam renang perlu dilaksanakan untuk mencegah penularan penyakit dan gangguan kesehatan Kadar sisa chlor merupakan salah satu parameter penting dalam penyehatan air kolam renang. Tujuan penelitian ini mengetahui kadar sisa chlor sebelum dan sesudah pemakaian air kolam renang Water Park Surya Yudha Kabupaten Banjarnegara. Jenis penelitian ini adalah penilitian deskriptif yang dilakukan dengan pengukuran kadar sisa chlor, kemudian dianalisis dan dibandingkan dengan ketentuan teori dan persyaratan kesehatan untuk kolam renang. Berdasarkan hasil pengukuran diketahui kadar sisa chlor air kolam renang berkisar antara 0,1 mg/l - 0,8 mg/l. Hasil pengukuran $\mathrm{pH}$ air kolam renang antara range $5-7$, pengukuran suhu kolam renang dalam range $24^{\circ} \mathrm{C}-28,5^{\circ} \mathrm{C}$, dan hasil pengukuran zat organik adalah 4,42 mg/l - 28,76 mg/l. Kesimpulan hasil pengukuran kadar sisa chlor air kolam renang menunjukkan bahwa masih terdapat kolam yang belum memenuhi syarat kesehatan baik sebelum maupun sesudah pemakaian. Peneliti menyarankan untuk penelitian selanjutnya tentang hubungan kadar sisa chlor pada air kolam renang dengan jumlah pengguna berdasarkan besarnya zat organik pada air kolam renang.
\end{abstract}

Kata Kunci : Sisa Chlor, Kolam Renang

\begin{abstract}
Chlorine Residual Levels Measurement Before And After The Water Used In The Surya Yudha Park Swimming Pool Banjarnegara Regency Year Of 2015. Pool health improvement implementation was needed to prevent diseases transmission and health problems. Chlorine residua level is one of the important parameters in swimming pool water sanitation. This research objective was; investigating chlorine residual levels before and after the water used in the Surya Yudha Park swimming pool Banjarnegara Regency. The research design used was descriptive, conducted by measuring the chlorine residual level, then analyzed and compared with theory and swimming pool health requirements. Based on measurements results the chlorine residual levels ranged from $0.1 \mathrm{mg} / \mathrm{l}-0.8 \mathrm{mg} / \mathrm{l}$. The $\mathrm{pH}$ measurement results was ranged 5-7, the pool temperature measurement ranged of $24{ }^{\circ} \mathrm{C}-28.5 \mathrm{C}$, and the organic substance measurement results was $4.42 \mathrm{mg} / \mathrm{l}-28.76 \mathrm{mg} / \mathrm{l}$. The conclusion drawn was; The chlorine residual results levels shows that there was swimming pool water that did not qualified health requirements, whether before and after use. Researchers suggested for further research on the relationship level of residual chlorine in the pool water with the number of users based on the amount of organic matter in swimming pool water.
\end{abstract}

Keywords : Chlorine Residual, Swimming Pool

\section{PENDAHUluAN}

Upaya penyehatan kolam renang perlu dilaksanakan untuk mencegah penularan penyakit dan gangguan kesehatan serta untuk mendorong pengembangan pariwisata dan olahraga secara nasional (Permenkes RI No. 061/MENKES/PER/1/1991). Salah satu upaya penyehatan kolam renang adalah proses desinfeksi. Desinfeksi yang umum digunakan pada kolam renang yaitu klorinasi.

1) Email : kencana.handayani16@gmail.com

2) Email : sugengzend@yahoo.com
Kolam renang Water Park Surya Yudha tidak dilakukan proses klorinasi secara kontinyu, sehingga diduga kadar sisa chlor tidak stabil dan perlu dilakukan pemeriksaan karena dimungkinkan tidak selalu dalam range $0,2-0,5 \mathrm{mg} / \mathrm{l}$ seperti yang diharuskan. Apabila kadar sisa chlor dalam air kolam tidak memenuhi syarat maka dapat terjadi penularan penyakit melalui air yang mengandung mikroorganisme.

Tujuan penelitian ini adalah mengetahui kadar sisa chlor air kolam renang sebelum dan sesudah pemakaian 
air kolam renang di Water Park Surya Yudha Kabupaten Banjarnegara.

\section{METODE}

Jenis penelitian ini adalah deskriptif, yakni pengukuran kadar sisa chlor dilakukan pada 5 kolam renang yang ada. Pengambilan sampel 2 kali yaitu sebelum dan sesudah digunakan. Pengukuran kadar sisa chlor menggunakan DPD Comparator Test Kit. Hasil pengukuran dianalisis dan dibandingkan dengan ketentuan teori dan persyaratan kesehatan untuk kolam renang.

\section{III.HASIL DAN PEMBAHASAN}

Hasil

Kadar sisa chlor rata-rata air kolam renang sebelum pemakaian pagi hari yaitu $0,3 \mathrm{mg} / \mathrm{l}$ dan sesudah pemakaian sore hari adalah $0,2 \mathrm{mg} / \mathrm{l}$. Jumlah pengunjung pada akhir pekan 368 orang sedangkan pada hari biasa 127 orang. Waktu penggunaan air kolam renang selama 9 jam. Hasil pengukuran $\mathrm{pH}$ air kolam renang antara range $5-7$, pengukuran suhu kolam renang dalam range $24^{\circ} \mathrm{C}-28,5^{\circ} \mathrm{C}$, dan hasil pengukuran zat organik adalah 4,42 mg/l - 28,76 mg/l.

\section{Pembahasan}

Menurut Permenkes RI No. 416/ MENKES/Per/IX/1990 menyatakan bahwa syarat kimia yaitu kandungan chlor yang dianjurkan $0,2 \mathrm{mg} / \mathrm{l}$ - 0,5 mg/l. Berdasarkan hasil pengukuran sisa chlor Minggu 14 Juni 2015, sebelum digunakan masih terdapat hasil yang tidak memenuhi syarat. Kadar sisa chlor kolam $40 \mathrm{~cm}, 80 \mathrm{~cm}$, dan kolam arus diatas standar yang ditetapkan, sedangkan kolam ombak tsunami masih kurang dari standar Setelah digunakan kadar sisa chlor kolam $150 \mathrm{~cm}$ dan kolam arus sudah memenuhi syarat.

Pengukuran pada hari Selasa 16 Juni 2015, sebelum digunakan hanya kolam $40 \mathrm{~cm}$ yang sisa chlornya melebihi standar. Sisanya sudah memenuhi syarat kesehatan. Setelah digunakan, pada kolam $40 \mathrm{~cm}$ dan kolam $150 \mathrm{~cm}$ masih memenuhi syarat. Sisanya dibawah standar dari Permenkes RI No.416/Menkes/Per/ IX/1990.

Bertambahnya pengunjung akan meningkatkan kadar zat organik pada air kolam renang. Saat berenang tubuh manusia akan mengeluarkan zat - zat organik yang dalam batas tertentu dapat mengurangi kadar sisa klor karena terjadi proses oksidasi. Menurut Tjokrokusumo (1995, h. 127) pada klorinasi dimana terdapat zat organik, desinfektan akan turun daya desinfeksinya disebabkan terjadinya klorinasi pada zat organik.

Hasil pengukuran $\mathrm{pH}$ pada air kolam renang berkisar antara $5-7$, masih termasuk dalam batas standar yang ditetapkan Permenkes RI No. 416/MENKES/Per/IX/1990 yaitu 6,5 - 8,5. Robert L. Jolley (1975, h. 40), menyebutkan bahwa pada $\mathrm{pH}$ yang lebih rendah efektivitas klorin dalam membunuh kuman lebih baik dari pada $\mathrm{pH}$ yang lebih tinggi, karena $\mathrm{pH}$ yang rendah dengan konsentrasi chlor bebas tersedia yang sama akan menghasilkan $\mathrm{HOCl}$ lebih banyak dari pada $\mathrm{OCl}^{-}$. $\mathrm{HOCl}$ lebih bersifat desinfektan daripada $\mathrm{OCl}^{-}$.

Hasil pengukuran suhu air kolam renang Water Park Surya Yudha berkisar antara $24^{\circ} \mathrm{C}-28,5^{\circ} \mathrm{C}$. Menurut Soebagio R (1978, h. 11) bahwa suhu air yang makin tinggi akan meningkatkan efektivitas klorin untuk desinfeksi. Kondisi tersebut juga mempengaruhi kebutuhan klor untuk desinfeksi, suhu air menurun maka kebutuhan klor meningkat, dan apabila suhu meningkat kebutuhan klor relatif lebih sedikit. Berdasarkan hal tersebut, pihak pengelola seharusnya dapat menghemat kebutuhan klor dengan suhu yang relatif tinggi.

Hasil pemeriksaan zat organik berkisar antara 4,42 $\mathrm{mg} / \mathrm{l}$ - 28,76 mg/l. Pada akhir pekan hasil rata-rata pengukuran zat organik setelah digunakan adalah 18,89 mg/liter dengan jumlah pengunjung 368 orang. Pengukuran pada hari biasa setelah digunakan yaitu 8,15 mg/liter dengan jumlah pengunjung 127 orang. Peneliti menyimpulkan bahwa semakin banyak jumlah pengunjung kolam renang akan semakin besar zat organik yang dihasilkan.

\section{IV.SIMPULAN DAN SARAN}

\section{Simpulan}

Hasil pengukuran kadar sisa chlor air kolam renang sebelum dan setelah pemakaian pada kolam $40 \mathrm{~cm}$, kolam $80 \mathrm{~cm}$, kolam arus, dan kolam ombak tsunami belum memenuhi syarat kesehatan, menurut Permenkes RI No.416/Menkes/Per/IX/1990 Tentang Persyaratan Kualitas Air Bersih.

\section{Saran}

Peneliti menyarankan untuk penelitian selanjutnya tentang hubungan kadar sisa chlor pada air kolam renang dengan jumlah pengguna berdasarkan besarnya zat organik pada air kolam renang.

\section{DAFTAR PUSTAKA}

Depkes RI. (1990). Peraturan Menteri Kesehatan RI No. 416/MENKES/Per/1990 Tentang Persyaratan Kualitas Air Kolam Renang. Jakarta : Departemen Kesehatan RI

Effendi Hafni. (2003). Telaah Kualitas Air Bagi Pengelolaan Sumberdaya Dan Lingkungan Perairan. Yogyakarta: Kanisius 
Jurnal Kesehatan Lingkungan Vol 7 No. 1 Juli (2013). http://journal. unair.ac.id/filerPDF/. Diakses pada 20 November 2014

Nur Dwi Tiyastuti. (2010). Studi Kadar Sisa Chlor Menurut Waktu Pemakaian Air Kolam Renang Purbasari Kecamatan Padamara Kabupaten Purbalingga Tahun 2010. Karya Tulis Ilmiah, Purwokerto: Poltekkes Semarang Jurusan Kesehatan Lingkungan Purwokerto

Perdana Kimia. (2014). Spesifikasi Produk TCCA Trichloroiso cyanuric Acid 90\% Tablet Granular. $\quad$ http://www. Perdana kimia.com/product/tcca-trichloro isocyanuricacid-p139460.aspx. diakses pada 30 Juni 2015 pukul 21:03

Reksosoebroto Soebagio. (1978) Hygiene \& Sanitasi. Jakarta : APKTS

Sidik Pramono. (2010). Studi Hubungan Pemakaian Air Kolam Renang Tirta Asri Dengan Kualitas Air Kolam Renang Di Desa Walik Kecamatan Kutasari Kabupaten Purbalingga Tahun 2010, Karya Tulis Ilmiah. Purwokerto: Poltekkes
Semarang Jurusan Kesehatan Lingkungan Purwokerto

Suparlan. (1994) Pedoman Pengawasan Sanitasi Tempat Tempat Umum Dan Tempat Wisata. PAM-SKL Ujungpandang

(2012) Pengawasan Hygiene - Sanitasi Tempat-Tempat Umum - Wisata \& UsahaUsaha Untuk Umum. Surabaya: Duatujuh

Suparmin. (2003). Kimia Untuk Air Dan Air Limbah. Politeknik Kesehatan Semarang Jurusan Kesehatan Lingkungan Purwokerto

Sutrisno Totok. (2011) Teknologi Penyediaan Air Bersih. Jakarta: Rineka Cipta

Tjokrokusumo. (1995). Konsep Teknologi Bersih Khusus Pengelolan Dan Pengolahan Air. Yogyakarta: Sekolah Tinggi Teknik Lingkungan YLH

Uber mas. (2015). TCCA 90\% Chlorine 90\%, Surabaya, http://ubermas.indonetwork.co.id/3500158. diakses pada tanggal 30 Juni 2015 pukul 20:45 